\title{
RELOADING OF GASTRONOMY TOURS IN THE CONDITIONS OF USING THE RIGHT-BANK POLISSIA GASTRONOMY POTENTIAL
}

\author{
Inna NESTERCHUK \\ Polissia National University, Faculty of Economics and Management, Department of Tourism, \\ Old Boulevard Street, 7, 10008, Zhytomyr, Ukraine, e-mail: nester_geoek@ukr.net \\ Anna OSIPCHUK* \\ Polissia National University, Faculty of Economics and Management, Department of Tourism, \\ Old Boulevard Street, 7, 10008, Zhytomyr, Ukraine, e-mail: annaosipchuck@ukr.net \\ Eduard BONDARENKO \\ Taras Shevchenko National University of Kyiv, Faculty of Geography, Department of Geodesy and \\ Cartography, ave. Academician Glushkov, 2, 03680, Kyiv, Ukraine, e-mail: edbe@ukr.net

\section{Oksana TRUSIJ} \\ Taras Shevchenko National University of Kyiv, Faculty of Geography, Department of Economic and \\ Social Geography, ave. Academician Glushkov, 2, 03680, Kyiv, Ukraine, e-mail: oktrusij@ukr.net \\ Valentyna IVANENKO \\ International Academy of Certification of Accountants and Auditors, \\ Malopidvalna Street, 10, 01001, Kyiv, Ukraine, e-mail: ivanenko2112@gmail.com

\section{Lyudmyla CHYZHEVSKA} \\ Zhytomyr state politechnical university, Faculty of Business and Service, Department of Information Systems in \\ Management and Accounting, Chudnovska Street, 103, 10005, Zhytomyr, Ukraine, e-mail: chizhev@ ztu.edu.ua
}

\begin{abstract}
Citation: Nesterchuk, I., Osipchuk, A., Bondarenko, E., Trusij, O., Ivanenko, V., \& Chyzhevska, L. (2021). RELOADING OF GASTRONOMY TOURS IN THE CONDITIONS OF USING THE RIGHT-BANK POLISSIA GASTRONOMY POTENTIAL. GeoJournal of Tourism and Geosites, 34(1), 170-176. https://doi.org/10.30892/gtg.34122-633
\end{abstract}

\begin{abstract}
The article is devoted to the development of methods for creating and updating gastronomic tours in terms of realizing the tourist potential of the Right-Bank Polissia and in connection with the demand of potential domestic and foreign tourists. The method of calculating the gastronomic potential of the Right Bank Polissia has been shown, the geovisualization of which is carried out by developing a series of author 's thematic cartographic models. The map "Gastronomic tastes of the Right-Bank Polissia festivals" will help to show the route to the Right-Bank Polissia, which contains popular gastronomic events, food museums and other infrastructural objects related to gastronomic tourism with well-thought-out logistics and price policy.
\end{abstract}

Key words: gastronomic tour, economic analysis of gastronomic potential, Right-Bank Polissia, thematic cartographic models, nature-based tourism, tourist destinations

\section{INTRODUCTION}

The pace of tourism development in the world has been steadily gaining momentum until the early spring of 2020 , when the vast majority of countries introduced strict national quarantine restrictions related to the CoVID-19 pandemic. Scientists have substantiated new types of tourism, formed new tourist destinations, and travel companies presented new tourist products. New forms of gastronomic tourist services appeared on the tourist market every year: live excursions, lectures, master classes. In general, gastronomic tours in the absence of any restrictions allow tourists to "taste" a familiar place, take part in the festival or learn to cook a favorite indigenous dish from its creators. Combining these examples with elements of other types of tourism, you can form a rich variety of gastronomic tourist offers for every taste.

\section{FORMULATION OF THE PROBLEM}

Gastronomic tourism is just beginning its development in our country, and especially in regions remote from the capital. Underestimation by tour operators of Polissia region, prospects for the development of various gastronomic tours to attract new customers, and the destination development slow down this process. Awareness of the need to create a competitive gastronomic tourism product that meets the interests of tourists and is in demand is a significant condition for the growing popularity of gastronomic tourism in the region and the country. Now there is a need to compile maps of the gastronomic potential, gastronomic festivals, a gastronomic tour of Right-Bank Polissia, and the development of the author's method of determining gastronomic potential.

\section{ANALYSIS OF RECENT PUBLICATIONS}

A great number of the scientists have studied the gastronomic tourism, potential and tour: Beidyk (2001); Vetkin (2013); Gordin (2014); Kolenda (2006); Linkova (2015); Liubitseva (2008) and others. Researches in the field of the gastronomic tourism are developed by such foreign scientists as Curtis (2010); Hamarneh (2017); Privitera (2018); López-Guzmán (2018).

The aim of the article is to develop a gastronomic tour of Right-Bank Polissia for domestic and foreign tourists on the basis of the marketing research of the Ukrainian and foreign tourists' gastronomic tastes. Tasks of the article: to develop a method of creating and updating gastronomic tours in terms of realizing the tourist potential of the Right-Bank Polissia in connection with the demand of 
potential domestic and foreign tourists and the possibility of consuming tourist services in a convenient, dynamic and modern information environment; to develop a series of author's thematic cartographic models; to create a new tourist product: a map "Gastronomic tastes of the Right-Bank Polissia festivals" in the Right-Bank Polissia of Ukraine.

\section{RESEARCH METHODOLOGY AND METHODS}

The methodological tool of the study is a set of general scientific and special methods. The scientific method in tourism is a system of approaches and methods that corresponds to the subject and objectives of this science. Descriptive, statistical, and graphic methods contribute to the study of the tourist specialization. The cartographic method is a systematization and generalization of the geographical research results in the form of cartographic models, maps, and schematic maps (Ostapchuk, 2014; Shevchenko, 2007; Bondarenko, 2007). In the explorations of the geography of tourism there is a return from quantitative methods to qualitative analysis using sociological, psychological and ethnological methodologies, as well as the application of economic theory and the theory of management, marketing. Qualitative indicators that are widely used in geographical practice include the so-called Baretti and Defert coefficient, which indicates the level of development of the tourist function. The SWOT method was used to determine opportunities for tourism development in a particular area. MS Excel 2007 is used in computer systematization of material in spreadsheets; ArcGIS 10.2 geoinformation system, Adobe Photoshop raster graphics editor, Adobe Illustrator vector graphics editor are used when creating experimental map samples and developing mapping techniques. In the conditions of the information society development, the mathematical methods play an important role while studying tourism, in particular economicmathematical and social-spatial models with use of computer technologies (Kuzyk, 2011). Few Ukrainian works (Liubitseva, 2008; Beidyk, 2001; Malska, 2006) are devoted to the theoretical foundations of the tourism geography development. There are few theories and concepts of this field in the foreign literature, the main accents are covered in the works of Cohen (2004); MacCannel (1996); Przecławski (2004). Therefore works of foreign scientists are mainly used. They include the work of Polish scientist Kowalczyk "Geografia turyzmu"(2000).

The material of the study is based on samples of the gastronomic Internet discourse: culinary sites, blogs, forums of the Internet communities, the Internet versions of the media, the Internet comments, and the Internet resources videos. According to the analysis, the empirical data on the tourist taste preferences representation are obtained. In addition, the material of the study is the results of an experiment conducted with the participants of the gastronomic Internet discourse, as well as quantitative data obtained from queries of the Internet search engines.

\section{PRESENTATION OF THE BASIC MATERIAL OF THE RESEARCH}

The gastronomic culture structure as a system includes three main elements, namely culinary culture, food culture and gastronomic reflection. Gastronomic culture performs the following functions: regulatory; communicative; broadcast; functions of identification, integration and labeling of social and cultural status of the individual. The main function should be considered to be the regulatory function and the function of marking social and cultural status. National cuisine is a cultural construct of the modern era, which emerged in the process of nationbuilding, which presents national culture and identity at the level of everyday life. The representational nature of the national cuisine has led to the predominant translation of the core of gastronomic culture, which sets the basic rules for combining products and determines the range of possible dishes. Ritualized confirmation and consolidation of the norms of gastronomic culture in the national cuisine becomes the basis for their "profanation" in everyday practice. The specificity of the existence of the considered forms of the gastronomic culture representation in Ukraine is associated with the significant irrelevance of these forms to the socio-cultural conditions of Ukrainian society. Gastronomic tourism has its own specific features (Gordin, 2014) and factors (Linkova, 2015). It has been revealed the growing dynamics of demand for gastronomic tours at the present stage of the tourism industry development in research. Due to the growing ethnocultural interest of society to learn about its own history and world cultural and historical space, authors propose to aggregate ethnic research and gastronomic tourism in a specific type of tourism, which will diversify the final products of the tourism industry through synergies.

Each territory has its own face. The preservation of architectural monuments and the historical appearance of cities and settlements has long been talked about, and the gastronomic face of the territory of the Right Bank Polissia has its own background. Gastronomic tourism has a huge cultural and cognitive function: it creates conditions for interaction and coexistence of different cultures, religions and traditions, provides an opportunity to see the national housing of peoples, their traditions and customs, taste national cuisine, get acquainted with hospitality and traditional life. This, ultimately, leads to the strengthening and establishment of interethnic relations of different ethnic groups. According to the author Nesterchuk (2020), gastronomic tourism is one of the promising areas of the ethnocultural revival of the world, which determines its essence and socially significant role in the global development of tourism and society as a whole.

However, in the modern world, gastronomic tourism is characterized by diversity and ambiguity, as it is closely connected with economics, culture, history, geography, architecture and many other sciences. Accordingly, gastronomic tourism is characterized by many different features, which are embodied in various indicators with different units of measurement. Thus, to give a holistic assessment of the level of development of gastronomic tourism in a region using traditional methods is a complex and time consuming process. This necessitates the expansion of the mechanism of using methods of economic analysis, in particular, the active use and creative processing of research techniques in related fields (mathematics, statistics, cybernetics, micro- and macroeconomics, etc.) is possible and scientifically grounded today. One of the solutions to this problem is the use of statistical methods of comparative multidimensional analysis in economic research, which are based on the distribution of multidimensional random variables, in particular, the method of taxonomy, which allows to solve the analyzed heterogeneity of the set of factors. Based on the method of taxonomy, a generalized assessment of a complex object or process is performed by calculating an integrated indicator, which is a synthetic value of all uniformly acting features that characterize the units of the study population and provides identification of the most influential factors. To assess the level of the gastronomic tourism development in Right-Bank Polissia, such a "combined" value should be an indicator of the gastronomic potential, which includes appropriate resources, reserves and opportunities for their use.

Currently, taxonomic analysis has become very popular in the study of complex multifactorial objects. The wide application for the analysis of various directions of scientific thought in various scientific fields (for example, in sports, philology, agriculture, pedagogy, archeology, ecology, economy, geography and other modern sciences, indicates the universality of this method better than any other evidence. The mentioned above convinces the expediency of using the taxonomic analysis to assess the level of the gastronomic tourism development. Comparative analysis of the scientific literature (Andrusiv et al., 2020; Bak, 2013; Baranovsky et al., 2018; Dopp et al., 2019; Hydzik, 2012; Kinash et al., 2019; Kolenda, 2006; Kopiński, 2014; Petrovska, 2016; Pociecha, 2008; Pociecha et al., 1988; Ridyard et al., 2015; Rozmus, 2016; Stanisławski, 2010), is used to identify the "classical" stages of the taxonomic analysis: "input information system formation" $\rightarrow$ "observation matrix construction" $\rightarrow$ "observation matrix values standardization" $\rightarrow$ "differentiation of features into stimulators and destimulators" $\rightarrow$ "reference vector formation" $\rightarrow$ "distance matrix construction" $\rightarrow$ "taxonomic indicator calculation for each object research" $\rightarrow$ "taxonomic analysis structure assessment". Also the works of Polish scientist Pliuta are quite important in 
addressing the use of taxonomic method (Pluta, 1976). In order to form the initial data for the taxonomic analysis of Right-Bank Polissia gastronomic potential on the basis of expert assessments, a system of indicators has been selected for three objects (Zhytomyr Polissia, Volyn Polissia, Rivne Polissia): gastronomic events (number of gastronomic festivals and other gastronomic events), tourist infrastructure (number of hotels, restaurants, green estates, museums related to gastronomy, monuments dedicated to food and beverages), food industry (factories and plants) and agricultural production (agricultural firms, farms). On the basis of the initial information the matrix of observations of $X$ dimensionality $(m \times n)$ of values of characteristics (features) of multidimensional units is formed:

$$
\begin{aligned}
& \left(\begin{array}{l}
x_{1} \\
x_{2}
\end{array}\right) \quad\left(\begin{array}{llllll}
x_{11} & x_{12} & \ldots & x_{1 j} & \ldots & x_{1 n} \\
x_{21} & x_{22} & \ldots & x_{2 j} & \ldots & x_{2 n}
\end{array}\right) \quad-\mathrm{m} \text { is the number of units of } \mathrm{n} \text {-dimensional space corresponding to the }
\end{aligned}
$$

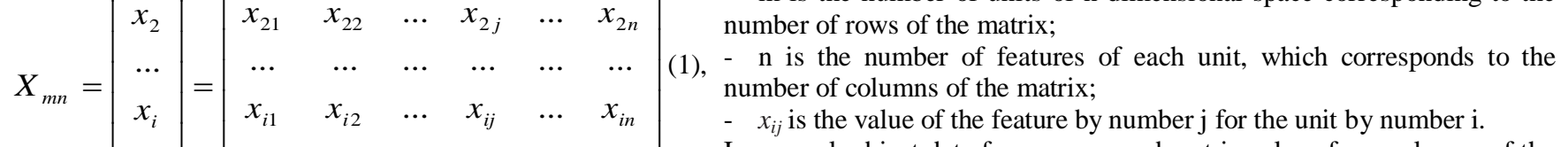

$$
\begin{aligned}
& \left(\begin{array}{c}
x_{i} \\
\ldots \\
x_{m}
\end{array}\right) \quad\left(\begin{array}{cccccc}
x_{i 1} & x_{i 2} & \ldots & x_{i j} & \ldots & x_{i n} \\
\ldots & \ldots & \ldots & \ldots & \ldots & \ldots \\
x_{m 1} & x_{m 2} & \ldots & x_{m j} & \ldots & x_{m n}
\end{array}\right)
\end{aligned}
$$

To calculate the integrated taxonomic indicator of gastronomic potential $\left(\mathrm{ITI}_{\mathrm{GP}}\right)$ on the basis of the collected data on the selected indicators of assessment of gastronomic tourism of Zhytomyr, Volyn, and Rivne regions the corresponding matrix of observations is constructed:

$$
X=\left|\begin{array}{cccc}
20 & 74 & 38 & 965 \\
21 & 16 & 117 & 899 \\
12 & 72 & 74 & 337
\end{array}\right|
$$

Since the selected indicators (criteria) for assessing the gastronomic potential describe different properties of the studied objects, they are inhomogeneous, with different units and, accordingly, incomparable. Then to ensure that they can be reduced to a single dimensionless value, the standardization of observation matrix is carried out by the following formula (Bąk, 2013; Kolenda, 2006; Pociecha et al., 1988):

$$
z_{i j}=\frac{x_{i j}-\overline{x_{j}}}{\sigma_{j}} \text { (3), } \quad \frac{z_{i j} \text { is the standardized feature } j \text { for the } i \text {-th object; }}{\boldsymbol{x}_{j}} \text { is the arithmetic mean value of the } j \text {-th indicator; }
$$

Since the selected indicators (criteria) for assessing the gastronomic potential describe different properties of the studied objects, they are inhomogeneous, with different units and, accordingly, incomparable. Then to ensure that they can be reduced to a single dimensionless value, the standardization of observation matrix is carried out by the following formula (Bąk, 2013; Kolenda, 2006; Pociecha et al., 1988).

$$
\sigma_{j}=\left[\frac{1}{m} \sum\left(x_{i j}-\overline{x_{j}}\right)^{2}\right]^{\frac{1}{2}}
$$

As a result of transformation of each value of the $x_{i j}$-th feature the following standardized matrix is formed:

$$
Z_{m n}=\left(\begin{array}{c}
z_{1} \\
z_{2} \\
\ldots \\
z_{i} \\
\ldots \\
z_{m}
\end{array}\right)=\left(\begin{array}{cccccc}
z_{11} & z_{12} & \ldots & z_{1 j} & \ldots & z_{1 n} \\
z_{21} & z_{22} & \ldots & z_{2 j} & \ldots & z_{2 n} \\
\ldots & \ldots & \ldots & \ldots & \ldots & \ldots \\
z_{i 1} & z_{i 2} & \ldots & z_{i j} & \ldots & z_{i n} \\
\ldots & \ldots & \ldots & \ldots & \ldots & \ldots \\
z_{m 1} & z_{m 2} & \ldots & z_{m j} & \ldots & z_{m n}
\end{array}\right)
$$

All elements of the formed standardized matrix have zero value of mathematical expectation and unit value - variances.

Based on the data of the observation matrix, the mean values and standard deviations are calculated for each indicator of the gastronomic potential in the system of initial data of the three regions (Table 1).

Table 1. The results of intermediate calculations for the standardized matrix construction (Source: own research)

\begin{tabular}{|c|c|c|c|c|}
\hline Indicators & Gastromonic events & Tourist infrastructure & Food industry & Agricultural production \\
\hline$\overline{\boldsymbol{x}_{\boldsymbol{j}}}$ & 17.67 & 54.00 & 76.33 & 733.67 \\
\hline$\sigma_{\mathrm{j}}$ & 4.93 & 32.92 & 39.55 & 345.10 \\
\hline
\end{tabular}

Accordingly, to reduce the selected characteristics to a common integrated indicator, the standardized matrix has the following form:

$$
Z=\left|\begin{array}{cccc}
0.47 & \mathbf{0 . 6 1} & -0.97 & \mathbf{0 . 6 7} \\
\mathbf{0 . 6 8} & -1.15 & \mathbf{1 . 0 3} & 0.48 \\
-1.15 & 0.55 & -0.06 & -1.15
\end{array}\right|(6)
$$

The next step is to differentiate the selected features by dividing them into stimulators (indicators, the increase of which improves the overall assessment of the study object function) and destimulators (lead to deterioration of the study object function), taking into account the impact of each indicator (factor) on the level of the gastronomic potential development. This feature distribution is the basis for the construction of the reference vector, which is formed on the basis of the principle that features with maximum values are selected among the features-stimulators, and with minimal - among the features- destimulators. The selection of reference points according to each indicator of the study object functioning level is carried out taking into account the fact that in one-dimensional space there is a pairwise comparison of indicators. For each indicator, the reference point is the distance to which the integrated indicator of the ga stronomic potential development level of the region is calculated. Therefore, we distinguish the "best" values in terms of the analyzed features and the purpose of the study (maximum or minimum) $z_{0 j}$ among all $m$ o units for each $j$-th feature of the matrix of standardized features vertically 
and form the coordinates of the reference vector: $z_{\mathrm{O} j}=\left(z_{\mathrm{O} 1}, z_{\mathrm{O} 2}, \ldots, z_{\mathrm{O} \mathrm{m}}\right)$. In this case, the coordinates of the reference point are:

$$
\left\{\begin{array}{l}
z_{0 j}=\max z_{i j}, \text { if } \mathrm{j} \in I, \\
z_{\mathrm{O} j}=\min z_{i j}, \text { if } \mathrm{j} \notin I(j=1, \ldots \ldots m)
\end{array}, I\right. \text { is the set of stimulants. }
$$

In this case, all the selected indicators for assessing the level of the gastronomic potential development belong to the stimulants. In the above mentioned standardized matrix Z, reference points are highlighted in bold, which allows to form a corresponding vector-reference:

$$
Z_{\mathrm{Oj}}=(0.68 ; 0.61 ; 1.03 ; 0.67) \text {. }
$$

The next step is to build a matrix of distances between individual observations and elements of the reference vector:

$$
C_{m n}=\left(\begin{array}{c}
c_{1} \\
c_{2} \\
\ldots \\
c_{i} \\
\ldots \\
c_{m}
\end{array}\right)=\left(\begin{array}{cccccc}
c_{11} & c_{12} & \ldots & c_{1 j} & \ldots & c_{1 n} \\
c_{21} & c_{22} & \ldots & c_{2 j} & \ldots & c_{2 n} \\
\ldots & \ldots & \ldots & \ldots & \ldots & \ldots \\
c_{i 1} & c_{i 2} & \ldots & c_{i j} & \ldots & c_{i n} \\
\ldots & \ldots & \ldots & \ldots & \ldots & \ldots \\
c_{m 1} & c_{m 2} & \ldots & c_{m j} & \ldots & c_{m n}
\end{array}\right)
$$

$c_{i j}$ is the multidimensional Euclidean distance (quasi-distance) between the individual observations and the reference vector for each selected indicator of the level of the gastronomic potential development, which is determined by the formula (Bąk, 2013; Kolenda, 2006; Pociecha et al., 1988):

$$
c_{i j}=\left(z_{i j}-z_{0 j}\right)^{2}(8), \quad z_{0 j} \text { is the standardized value of the indicator } j \text { at the reference point. }
$$

According to the calculations, the distance matrix has the following form:

$$
C=\left|\begin{array}{llll}
0.043 & 0.000 & 3.997 & 0.000 \\
0.000 & 3.113 & 0.000 & 0.036 \\
3.349 & 0.004 & 1.186 & 3.310
\end{array}\right|(9) \text {. }
$$

Based on the formed distance matrix, the taxonomic distance between the individual observations and the reference vector ( $c_{i o}$ ) is determined by the formula (Bąk, 2013; Kolenda, 2006; Pociecha et al., 1988):

$$
c_{i \mathrm{O}}=\sqrt{\sum_{j=1}^{n}\left(z_{i j}-z_{\mathrm{O} j}\right)^{2}}
$$

$Z_{i j}$ is the standardized feature $j$ for the $\mathrm{i}$-th object; $Z_{o j}$ is the standardized value of the indicator $\mathrm{j}$ at the reference point. It should be taken into account that the closer the unit of the studied population to the reference point is, the smaller the value of $c_{i 0}$ is, and, respectively, the higher the quality of the studied feature is. Determining the taxonomic distance for each object is the basis for the final comprehensive assessment of the gastronomic tourism development level of Right-Bank Polissia by calculating the integrated taxonomic indicator of gastronomic potential ( ITI $\left._{\mathrm{GP}}\right)$ (Bąk, 2013; Kolenda, 2006; Pociecha et al., 1988):

$\mathrm{ITI}_{\mathrm{GP}}=1-d_{i}(11), d_{i}$ is the coefficient of taxonomy, which is calculated by the formula (Bąk, 2013; Kolenda, 2006; Pociecha et al., 1988):

$$
\begin{gathered}
d_{i}=\frac{c_{i 0}}{c_{0}}(12), \quad c_{0} \text { is the indicator of the quality of the studied object functioning: } \\
c_{0}=\bar{c}_{0}+2 \sigma_{0}(13), \quad \bar{c}_{0} \text { is the arithmetic mean of the previously calculated distances between the standardized } \\
\text { indicators of the } i \text {-th object and the reference: } \\
\bar{c}_{0}=\frac{\sum_{i=1}^{n} c_{i 0}}{n}(14), \quad \sigma_{0} \text { is a standard deviation from the } \\
\text { reference point: }
\end{gathered}
$$

The closer the value of the taxonomic indicator to the unit is, the better the level of the studied object is, in particular, the higher the level of the gastronomic potential development is. Continuing the consideration of the issue, it should be noted that the taxonomic analysis is incomplete, and the conclusions are insufficiently substantiated without determining the importance of the selected indicators in a comprehensive assessment of the phenomenon, in particular, the level of the gastronomic tourism development. To do this, it is necessary to analyze the structure of a comprehensive assessment obtained by the taxonomic method, by calculating the proportion of the contribution of each selected feature of the studied object in the integrated taxonomic indicator (Bąk, 2013; Kolenda, 2006; Pociecha et al., 1988):

$$
w_{i j}=\frac{\left(z_{i j}-z_{0 j}\right)^{2}}{\sum_{j=1}^{n}\left(z_{i j}-z_{0 j}\right)^{2}} \times 100(16), \quad w_{i j} \text { is the weight of the indicator in the assessment of the object under study. }
$$

The total impact of the selected indicators on the comprehensive assessment of the gastronomic potential level of the region is defined as the arithmetic mean of the calculated fractions:

$$
\overline{w_{j}}=\frac{\sum w_{i j}}{n}
$$

This indicator allows to determine the importance of each selected factor in a comprehensive assessment of the gastronomic potential development level, which, in its turn, helps to outline priority areas for further in-depth analysis of the gastronomic tourism development. 
Table 2 demonstrates the results of the final calculations of a comprehensive assessment of the gastronomic tourism development level of Right-Bank Polissia in 2019 by calculating the integrated taxonomic indicator of gastronomic potential.

Table 2. Estimated indicators for taxonomic analysis of the gastronomic tourism development level of Right-Bank Polissia in 2019 (Source: own research)

\begin{tabular}{|c|c|c|c|c|c|c|}
\hline Objects & $c_{i 0}$ & $\bar{c}_{0}$ & $\sigma_{\mathrm{o}}$ & $d_{i}$ & $I T I_{G P}$ & Rating \\
\hline Zhytomyr Polissia & 2.01 & \multirow{3}{*}{2.20} & \multirow{3}{*}{0.54} & \multirow{3}{*}{3.28} & 0.39 & 2 \\
\hline Volyn Polissia & 1.77 & & & & 0.46 & 1 \\
\hline Rivne Polissia & 2.80 & & & & 0.15 & 3 \\
\hline
\end{tabular}

Table 3. The assessment structure of the gastronomic potential level of Right-Bank Polissia in 2019 (Source: own research)

\begin{tabular}{|c|c|c|c|c|c|}
\hline Components of gastronomic & \multicolumn{3}{|c|}{ The structure of the taxonomic indicator of gastronomic potential by its components, $\%$} & \multirow{2}{*}{ Average weight } & \multirow{2}{*}{ Rating } \\
\hline potential & Zhytomyr Polissia & Volyn Polissia & Rivne Polissia & & \\
\hline Gastronomic events & 1.07 & 0.00 & 42.67 & 14.58 & 3 \\
\hline Tourist infrastructure & 0.00 & 98.82 & 0.06 & 32.96 & 2 \\
\hline Food industry & 98.93 & 0.00 & 15.10 & 38.02 & $\mathbf{1}$ \\
\hline Agricultural production & 0.00 & 1.18 & 42.17 & 14.44 & 4 \\
\hline Total & 100.00 & 100.00 & 100.00 & 100.00 & $\mathrm{X}$ \\
\hline
\end{tabular}

The conducted research demonstrates that in 2019 Volyn Polissia is in the lead, = and Rivne is in the last place. That is, according to the set of selected features Volyn region demonstrates the greatest level of the gastronomic tourism development in Right-Bank Polissia and Rivne Polissia is the least developed. In addition, if we use the Harrington scale (from 0.00 to 0.36 is a low level of development; from 0.36 to 0.64 is an average level; from 0.64 to 1.00 is a high level of development), we notice that a high level of the gastronomic touris m development is achieved in none of the studied areas in 2019, in particular, in Volyn and Zhytomyr Polissia there is an average level of development, and in Rivne it is very low. The satisfactory level of the gastronomic tourism development of Right-Bank Polissia can be explained first of all by modern conditions of "chronic" economic and political instability in Ukraine.

To strengthen the conclusions, it is necessary to consider the significance of each indicator selected for a comprehensive assessment of the gastronomic tourism development level in more detail. Therefore, on the basis of the distance matrix, the structure of taxonomic analysis of gastronomic tourism development in three regions of Right-Bank Polissia has been assessed. It has revealed the components of gastronomic potential that have the greatest impact on the formation of the relevant integrated taxonomic indicator (Table 3).

Analysis of the rating structure of the Right-Bank Polissia regions according to the level of gastronomic potential demonstrates that on average the volume of food industry in terms of the number of factories, plants and plants engaged in food production (38.01\%) has the largest impact on its construction in 2019 and availability of agricultural firms and farms (14.44\%) has the smallest one. At the same time, in terms of individual regions, various components of gastronomic potential prevail, in particular, in Zhytomyr region - the food industry (98.93\%), in Volyn region - tourist infrastructure (number of hotels, restaurants, green estates, museums associated with gastronomy, monuments dedicated to food and drink) (98.82\%) and in Rivne region - gastronomic events (number of gastronomic festivals and other gastronomic events) (42.67\%) and agricultural production (42.17\%). In general, the selected components of the gastronomic potential of the three regions of Right-Bank Polissia, which are factors influencing the level of its formation, can be placed from the most important to the least: food industry $\rightarrow$ tourist infrastructure $\rightarrow$ gastronomic events $\rightarrow$ agricultural production.

This sequence of gastronomic potential components allows to distribute them by priority in managing the level of the gastronomic tourism development in three areas of Right-Bank Polissia, because, while increasing more priority features along with others, the level of gastronomic potential of the region is growing faster. Thus, the integrated taxonomic indicator is a complex characteristic of the gastronomic potential of Right-Bank Polissia. The proposed model of taxonomic analysis allows to identify areas for improvement of gastronomic tourism management policy, as well as to determine the impact of external and internal threats on the level of gastronomic tourism in each of the studied areas further, and to form prerequisites for management strategy.

However, the developed model cannot take into account force majeure. In particular, the beginning of 2020 was marked by an ou tbreak worldwide of the coronavirus pandemic COVID-19, which mercilessly affected the tourism business around the world, including Ukraine, due to the closure of borders and the introduction of emergency quarantine measures. Obviously, this negatively affected all components of the gastronomic potential and caused irreparable damage to the gastronomic tourism market. Thus, due to the coronavirus pandemic, out of 30,000 catering companies, 12,000 were liquidated as economic entities (Nastych, 2020). According to the World Travel \& Tourism Council, the number of jobs threatened by the COVID-19 pandemic could reach 75 million. In Europe, up to 10 million jobs in the field of travel and tourism are at risk, a loss of almost 552 billion dollars. In Ukraine, losses are estimated at 0.5 million jobs. In addition, according to Cushman \& Wakefield Ukraine, at the end of the first half of 2020, Rack rates decreased for all categories of hotels in both dollars and hryvnias (compared to the same period last year). How events will develop in the future is quite difficult to predict. The in troduction of any stricter quarantine restrictions in Ukraine will only negatively affect all components of gastronomic potential (Grishina, 2020).

Thus, the gastronomic potential is a symbiosis of resources (tourist and recreational), reserves (use and practical implementation of inherent abilities: culinary, hotel and restaurant, institutional), opportunities (formation of new skills: culinary schools, workshops, blogs, tours, connection of a new model of mass media recreation), tourist infrastructure, producers of gastronomic tourist product, institutions, attractions for organization and implementation of tourist, recreational, gastronomic, hotel and restaurant, logistics, promotional activities in the region to meet human needs (Figure1). Promisingly, Kyiv Polissia in the future will be an attractive area for tourists with a set of tourist attractions and a developed tourist infrastructure. The availability and quality of tourist infrastructure determine the number of tourists who will visit the destination. The destination space has both physical-geographical and administrative boundaries that determine the form of government, the image of the territory and the level of competitiveness in the tourism market. Currently, Ukrainian cuisine is a tool for promoting the Ukrainian language in foreign restaurants of Ukrainian cuisine - as an object of gastronomic tourism. The considerable influence of gastronomic tourism on the region's economy is obvious: the use of products of local producers as one of the directions of tourism development, the system of gastronomic tourism product formation, import substitution in the food and tourism industry, etc.

Right-bank Polissia has significant potential for the development of multidisciplinary and highly efficient tourist and recreational economy. It is characterized by favorable natural and cultural-historical recreational resources. It attracts tourists not only with its unique forest and swamp landscapes, but also with a bright and colorful ethnocultural environment. At the present stage of the tourism industry development it is important to offer a new product that can interest an experienced consumer. Development of the gastronomic tour maps will help to promote gastronomic tourism in the Right-Bank Polissia (Figure 2). 


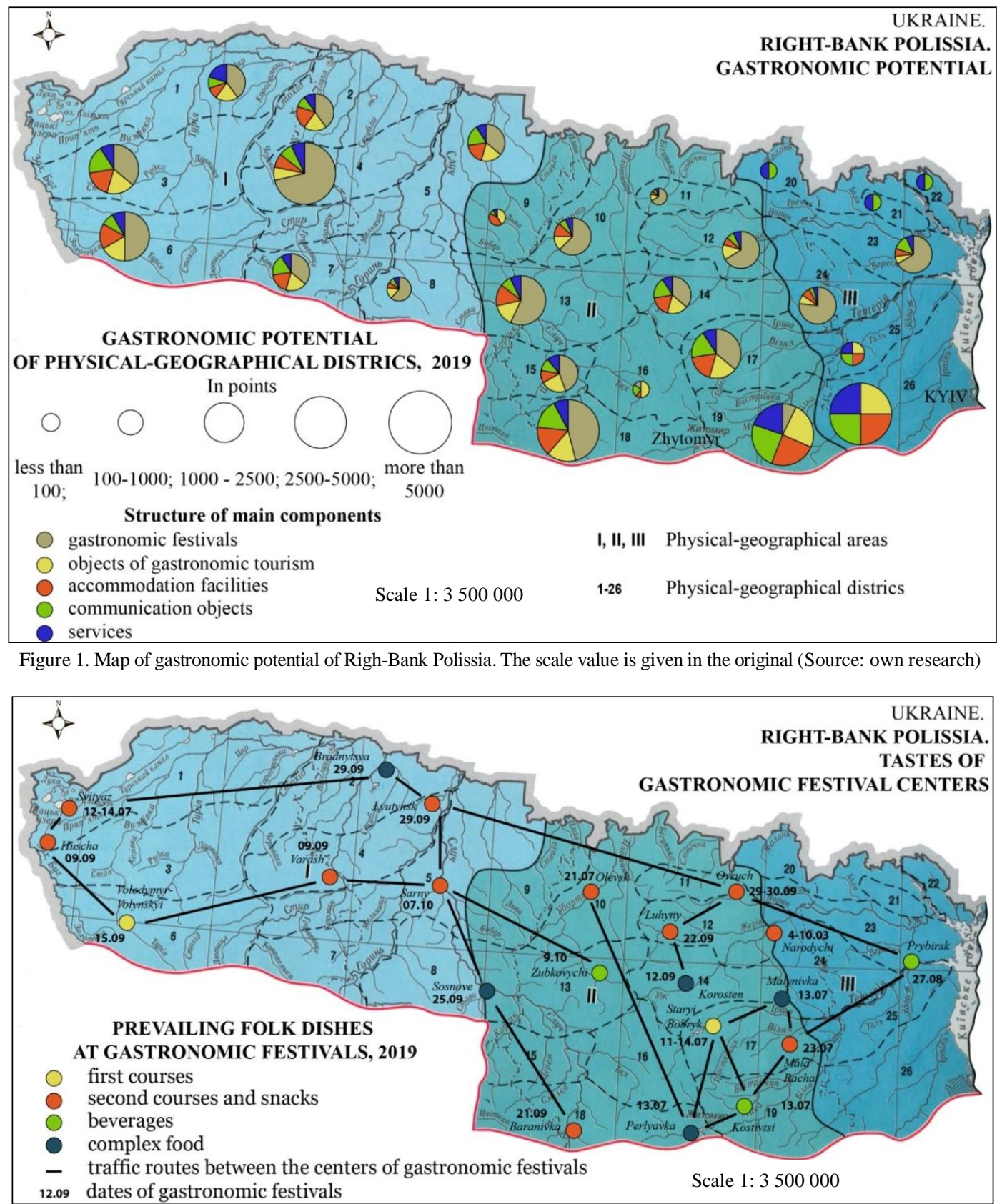

Figure 2. Map of the gastronomic tour "Gastronomic tastes of the Right-Bank Polissia festivals". The scale value is given in the original (Source: own research)

It is extremely important for a region that is developing and outlining its own branding curiosities in the field of tourism, recreation and entertainment to make this kind of scientific research in the field of gastronomic tourism. The objects of general analysis can be: a gastronomic tourist product, a gastronomic tour, a gastronomic tourist and a consumer basket of a gastronomic tourist, which will become resulting. The author's vision of the above mentioned definitions is offered:

$\checkmark \quad$ "a gastronomic tourist product" is a package of tangible and intangible elements (impressions, services, attractions, and tourist resources) that can be purchased within one trip to the destination;

$\checkmark \quad$ "a gastronomic tourist" is a tourist who travels with a clearly defined gastronomic purpose, regardless of financial status, visiting both high-end establishments and catering establishments, or street food or indigenous, traditional cuisine;

$\checkmark \quad$ "a gastronomic tour" is a specially selected program of gastronomic recreation, where taste impressions are put at the first place, while the visual impressions are additional;

$\checkmark \quad$ "a consumer basket of a gastronomic tourist" is a unique package of tourist services, that primarily includes a promotional gastronomic tour, which is spatially localized in the information and tourist hub of the visited gastronomic and indigenous attraction.

Public authorities are aware of the effectiveness of gastronomic tourism for the development of the country's economy and industry and create programs for their development in many countries, states, and cities (Alliance of Independent Gastronomic Specialists of Ontario Tourism, Chinese Academy of Social Sciences, The World Food Travel Association). Other institutions and organizations make a significant contribution to the development of the tourism industry. This contribution presents some results of research projects of the Department of Tourism: "Constructive-geographical and organizational-economic principles of development of innovative types of tourism in the territory of the Right-Bank Polissia" (State registration number 0117U007357); "Organizational and economic principles of ecological tourism development" (State registration number 0119U103399); "Gastronomic tourism: theoretical and methodological construct and prospects for the implementation of gastronomic research in the field of tourism, recreation" (State registration number 0119U103398). Scientific developments are used in the Program of inbound tourism of Zhytomyr region until 2030. 


\section{CONCLUSIONS AND PROSPECTS OF THE STUDY}

In summary, we can say that developing gastronomic tourism contributes to the socio-economic development of the Right-Bank Polissia region, including the creation of additional jobs, preservation or opening of enterprises, helping to brand the region in gen eral and its local parts, attracting tourist flows. Due to the mapping of gastronomic potential and the separation of gastronomic festivals as events of large-scale tourist significance in the Right-Bank Polissia, it is advisable to conduct gastronomic and tourist zoning.

The map of the gastronomic tour "Gastronomic tastes of the Right-Bank Polissia festivals" thanks to PR-technologies will allow to attract tourist flows to the destination of the Right-Bank Polissia.

\section{Acknowledgments}

The authors are grateful to Doctor of Economics, Professor V. Tarasova and Doctor of Economics, Professor E. Khodakivsky for their thoughtful suggestions and comments. We would also like to thank other colleagues at the university for the corrections and constructive comments.

\section{REFERENCES}

Andrusiv, U., Simkiv, L., Dovgal, O., Demchuk, N., Potryvaieva, N., Cherchata, A., Popadynets, I., Tkachenko, G., Serhieieva, O., \& Sydor, H. (2020). Analysis of economic development of Ukraine regions based on taxonomy method. Management Science Letters, 10(3), 515-522. https://doi.org/10.5267/j.ms1.2019.9.029

Bąk, A. (2013). Metody porządkowania liniowego w polskiej taksonomii - pakiet pllord [Linear ordering methods in Polish taxonomy - pllord package]. Prace Naukowe Uniwersytetu Ekonomicznego we Wrocławiu, 54-62, (in Polish). https://doi.org/10.15611/pn.2016.426.02

Baranovsky, O.I., Kopytko, M.I., \& Barilyuk, M.M.R. (2018). Using the taxonomy method to assess the level of financial security of a commercial bank. Financial and credit activities: problems of theory and practice, 1 (24), 4-14.

Beidyk, O.O. (2001). Recreational and tourist resources of Ukraine: methodology and methods of analysis, terminology, zoning, Kiev.

Bondarenko, E.L. (2007). Geoinformation ecological and geographical mapping, Kyiv.

Cohen, E. (2004). Contemporary tourism - trends and challenges: sustainable authenticity or contrived post-modernity? Tourism: Critical in the Social Sciences, vol. I, London, 179-201.

Curtis, J. (2010). Spices are the soul of curry. Kommersant Weekend Magazine, 44 (190).

Dopp, A., Mundey, P., Beasley, L., Silovsky, J., \& Eisenberg, D. (2019). Mixed-method approaches to strengthen economic evaluations in implementation research. Implementation Science, 14(1), 2. https://implementationscience.biomedcentral.com/articles/10.1186/s13012-018-0850-6

Gordin, V.E. (2014). Gastronomic brands of destinations: approaches and applications, Sankt-Peterburg.

Grishina, O. (2020). Hotels in quarantine: we work to the last client and implement innovations. https://propertytimes.com.ua/gostinichnaya_nedvizhimost/ goteli_na_karantini_pratsyuemo_do_ostannogo_klienta_ta_vprovadzhuyi_nova

Hamarneh, I. (2017). Local gastronomy as a prerequisite of food tourism development in the Czech Republic, Marketing \& Management of Innovations, 2, 15-25.

Hydzik, P. (2012). Zastosowanie metod taksonomicznych do oceny poziomu rozwoju społeczno-ekonomicznego powiatów województwa podkarpackiego [Application of taxonomic methods to assess the level of socio-economic development of poviats in Podkarpackie Province]. Humanities and Social Sciences, 19 (2), 17-32. (in Polish). https://doi.org/10.7862/rz.2012.einh.9

Kinash, I.P., Arkhypova, L.M., Polyanska, A.S., Dzoba, O.G., Andrusiv, U.Y., \& Iuras, I.I. (2019). Economic evaluation of tourism infrastructure development in ukraine. The IOP Conference Series: Materials Science and Engineering, 477(1). https://doi.org/10.1088/1757-899X/477/1/012020

Kolenda, M. (2006). Taksonomia numeryczna: klasyfikacja, porzadkowanie i analiza obiektów wielocechowych [Numerical taxonomy: classification, ordering and analysis of multi-feature objects]. Monografie i Opracowania, Wrocław, 355-358, (in Polish).

Kopiński, A. (2014). Taksonomia i zastosowanie metody Hellwiga w ocenie efektywności funduszy inwestycyjnych [Taxonomy and application of the Hell wig method in assessing the effectiveness of investment funds]. Prace Naukowe Uniwersytetu Ekonomicznego we Wrocławiu, 330, 192-204 (in Polish). http://wir.bg.ue.wroc.pl/docstore/download.seam?fileId=WUTb3fb639663134292927a18cbb88d2677

Kowalczyk, A. (2000). Geografia turyzmu [The geography of tourism], Wydawn. Nauk. PWN, (in Polish).

Kowalczyk, S. (2011). Geography of tourism, Kyiv.

Linkova, A.A. (2015). Modern tendencies in the organization of gastronomic tours. Resort and recreation complex in the system of regional development: innovative approaches, 1, 1, 209-213.

Lopez-Guzman, T., Torres Naranjo M., Pérez-Gálvez, J.C. \& Carvache Franco, W. (2018). Gastronomic perception and motivation of the tourist direction: the city of Quito, Ecuador. GeoJournal of Tourism and Geosites, 21(1 appendix), 61-73. http://gtg.webhost.uoradea.ro/PDF/GTG-1-2018/271_Guzman.pdf

Liubitseva, O.O. (2008). Tourism: introduction to the specialty, Kyiv.

Malska, M.P. (2006). Tourist local lore. Europe, Lviv.

Nastych, I. (2020). Falling congestion, lower rail rates and the composition of the recovery: the hotel business during COVID 19. Property times. https://propertytimes.com.ua/gostinichnaya_nedvizhimost/ padinnya_zavantazhenosti_znizhennya_rack_rates_ta_skladne_vidnesninyy

Nesterchuk, I., Osipchuk, A., Chernyshova, T., Shevchuk, B., \& Bondarenko, E. (2020). Ethnic loading of food as a sustainable culture component in the form of physical-geographical, soil and ethnographic zoning of the right-bank Polissia. GeoJournal of Tourism and Geosites, 30(2 supplement), 788-793. https://doi.org/10.30892/gtg.302spl02-506

MacCannel, D. (1976). The Tourist: A New Theory of the Leisure Class, New York.

Ostapchuk, S.M. (2014). Cartography: facts, materials, information, Rivne.

Petrovska, I. (2016). Language standards of the gastronomic offer. Conference: Conference: XIII International Scientific Conference on Service Sector INSCOSES 2016, Macedonia.

Pluta, W. (1976). Taksonomiczna procedura prowadzenia syntetycznych badań porównawczych za pomoca zmodyfikowanej miary rozwoju gospodarczego [Taxonomic procedure for conducting synthetic comparative studies using a modified measure of economic development]. Przegląd Statystyczny, 4, 511-517, (in Polish).

Pociecha, J. (2008). Rozwój metod taksonomicznych i ich zastosowań w badaniach społeczno-ekonomicznych. Statystyka społeczna. Dokonania - szanse perspektywy [Development of taxonomic methods and their applications in socio-economic research. Social Statistics. Achievements - opportunities prospects]. Konferencja naukowa inaugurująca obchody jubileuszu 90-lecia Głównego Urzędu Statystycznego, (in Polish). http://stat.gov.pl/cps/rde/ xbcr/gus/POZ_Rozwoj_metod_taksonomicznych.pdf

Pociecha, J., Podolec, B., Sokołowski, A., \& Zając, K. (1988). Metody taksonomiczne w badaniach społeczno-ekonomicznych [Taxonomic methods in socioeconomic research]. Warszawa.

Privitera, D., Nedelcu, A., \& Nicula, V. (2018). Gastronomic and food tourism as a local economic resource: examples from Romania and Italy. GeoJournal of Tourism and Geosites, 21 (1 appendix), 144-157. http://gtg.webhost.uoradea.ro/PDF/GTG-1-2018/276_Nedelcu.pdf

Przecławski, K. (2004). Człowiek a turystyka - zarys socjologii turystyki [Man and tourism - an outline of the sociology of tourism]. Krakow.

Ridyard, C.H., Hughes, D.A., Hollingworth, W., Noble, S., Thorn, J., Coast, J., \& Knapp, M. (2015). Taxonomy for methods of resource use measurement. Health Economics, United Kingdom, 24(3), 372-378. https://doi.org/10.1002/hec.3029

Rozmus, D. (2016). Badanie stabilności taksonomicznej czynnikowej metody odległości probabilistycznej [Investigation of the taxonomic stability of the factorial probabilistic distance method]. Prace Naukowe Uniwersytetu Ekonomicznego we Wrocławiu, Wrocław, 427, 176-183, (in Polish). https://doi.org/10.15611/pn.2016.427.18

Shevchenko, V.O. ( 2007). The wonderland of geoimaging, Kyiv.

Stanisławski, M. (2010). Ocena efektywności restrukturyzacji wybranego sektora gospodarki w Polsce z wykorzystaniem taksonomicznego miernika rozwoju społeczno-gospodarczego [Investigation of the taxonomic stability of the factorial probabilistic distance method]. Bank i Kredyt, 6, 85-104, (in Polish).

Vetkin, V.A. (2013). Technology of tourism product creation. Package tours: Educational and methodical manual, Moscow.

*** Alliance of Independent Gastronomic Specialists of Ontario Tourism [Electronic resource]. Access mode: https://ontarioculinary.com

*** Chinese Academy of Social Sciences. [Electronic resource]. Access mode: http://eng-lish.cas.cn

*** The World Food Travel Association. [Electronic resource]. Access mode: www.worldfoodtravel.org 